\title{
Risk factors associated with the epidemiology of Toxoplasma gondii in cattle and buffaloes in the state of Pará, Brazil
}

\section{Fatores de riscos associados à epidemiologia doToxoplasma gondii em bovinos e bubalinos no Estado do Pará, Brasil.}

\author{
Jefferson Pinto de Oliveira ${ }^{1 *}$; Alexandre do Rosário Casseb $^{2}$; Anelise de Sarges \\ Ramos $^{3}$; Sebastião Tavares Rolim Filho²; Henrique Low Nogueira ${ }^{4}$; Rogério \\ Oliveira Pinho5; Washington Luiz Assunção Pereira²
}

\begin{abstract}
Toxoplasma gondii is an obligate intracellular protozoan that parasitizes several hosts worldwide, of which cats are definitive hosts. The objective of this study is to evaluate the risk factors associated with the epidemiology of $T$. gondii in cattle and buffaloes in the state of Pará, Brazil. A total of 2,070 bovine samples (1,749 cattle and 321 buffaloes) were evaluated in 100 rural properties distributed in 51 municipalities from all mesoregions of the state. The evaluated risk factors were animal gender, type of farm, and number of cats in the properties. The serological prevalence of $T$. gondii was evaluated using the indirect enzyme immunoadsorption assay (iELISA). The samples with a sample/positive (S/P) ratio $\geq 0.5$ were considered positive and analyzed using the indirect immunofluorescence assay (IFA). The samples diluted at 1:64 were considered positive. The chi-square test with a level of significance of $5 \%$ and the odds ratio (OR) with a confidence interval of $95 \%$ was applied.The data were analyzed using BioEstat software version 5.0.The prevalence of T. gondii in bovines was $35.79 \%$ and $45.12 \%$ in ELISA and IFAT, respectively. The prevalence was $34.48 \%$ and $44.14 \%$ in cattle and $42.99 \%$ and $50.47 \%$ in buffaloes using ELISA and IFA, respectively. The mesoregion with the highest prevalence of infection was Marajó Island, corresponding to $42.86 \%$ (129) and 50.5\% (152) in ELISA and IFA, respectively. In buffaloes, the prevalence of $T$. gondiiusing ELISA was higher in males $(p<0.05)$ in the two age groups. In contrast, the prevalence of $T$. gondii using IFA was higher in males in the age group 13 to 24 months $(\mathrm{p}<0.05)$. The type of farm did not affect the prevalence of $T$. gondii in cattle $(\mathrm{p}>0.05)$. However, the presence of cats strongly affected the occurrence of infection in cattle. These results demonstrate the high levels of anti-T. gondii antibodies in cattle and buffaloes in Pará and this may be a public health problem. Furthermore, the presence of cats is a risk factor for infection with $T$. gondii in these species in Pará.
\end{abstract}

Key words: Toxoplasmosis. Bovine. ELISA. IFA.

\footnotetext{
${ }^{1}$ Médico Veterinário, Diretor de Defesa e Inspeção Animal, Agência de Defesa Agropecuária do Estado do Pará, ADEPARA, Belém, PA, Brasil. E-mail: jeffersonpo@bol.com.br

2 Profs., Universidade Federal Rural da Amazônia, UFRA, Belém, PA, Brasil.E-mail: alexcasseb@yahoo.com.br; sebastiaorolim@ yahoo.com.br; wkarton@terra.com.br

3 Médica Veterinária, Residente em Reprodução Animal, UFRA, Belém, PA, Brasil. E-mail: anelise_sargesramos@outlook.com.br

4 Discente de Ciências Biológicas, Universidade da Amazônia, UNAMA, Belém, PA, Brasil. E-mail: henriquelow9@gmail.com

5 Pesquisador em Reprodução Animal, Minitub Brasil, Porto Alegre, RS, Brasil. E-mail: rogério_op@yahoo.com.br

Author for correspondence
} 


\section{Resumo}

O Toxoplasma gondii é um protozoário intracelular obrigatório de ocorrência mundial e se encontra parasitando uma grande diversidade de hospedeiros, sendo os gatos de fundamental importância para o ciclo de vida do parasita. O presente estudo teve como objetivo avaliar os fatores de riscos associados a epidemiologia doToxoplasma gondii em bovinos e bubalinos no Estado do Pará, Brasil. Foram avaliadas 2.070 amostras de bovídeos, sendo 1.749 bovinos e 321 bubalinos, em 100 propriedades rurais distribuídas em 51 municípios, envolvendo todas as mesorregiões do Estado. Os fatores de risco avaliados foram sexo, exploração pecuária e número de gatos existentes nas propriedades. A prevalência sorológica de Toxoplasma gondii foi avaliada pelo Ensaio de Imunoadsorção Enzimático Indireto (iELISA), considerando-se positivas as amostras que obtiveram razão $\mathrm{S} / \mathrm{P}$ (sample/positive) $\geq 0,5$, bem como, submetidas a Reação de Imuno fluorescência Indireta (RIFI), sendo positivas as amostras regentes na diluição 1:64. Foi aplicado o teste do Qui-quadrado com 5\% de significância e empregado cálculo da razão de chances (OR), com um intervalo de confiança de $95 \%$. Todos os resultados foram tratados estatisticamente pelo software BioEstat 5.0. A prevalência de T. gondii nos bovídeos foi de $35,79 \%$ e $45,12 \%$ no ELISA e RIFI, respectivamente. Em bovinos a prevalência foi de $34,48 \%$ e $44,14 \%$ e em bubalinos de $42,99 \%$ e 50,47\% no ELISA e RIFI, respectivamente. A mesorregião com maior prevalência foi a do Marajó com42,86\% (129) e 50,5\% (152) no ELISA e RIFI respectivamente. Em relação aos bubalinos a prevalência de $T$. gondii foi mais elevada em macho $(\mathrm{P}<0,05)$ nas duas faixas etárias avaliadas pelo ELISA. Já pelo RIFI a prevalência foi maior em machos somente na faixa etária de 13 a 24 meses $(\mathrm{P}<0,05)$ não tendo influência do sexo nos bovinos. $\mathrm{O}$ tipo de exploração também não influenciou a prevalência de $T$. gondii em bovídeos $(\mathrm{P}>0,05)$, porém a presença de gatos teve grande significância na ocorrência de infecção em bovídeos. Os resultados demonstram a elevada presença de anticorpos anti - T. gondii em bovinos e bubalinos no Estado do Pará, o que poderepresentar risco para saúde pública, além do que a presença de gatos é umfator de risco para a infecção por $T$. gondii nessas espécies no estado do Pará.

Palavras-chave: Toxoplasmose. Bovídeos. ELISA. RIFI.

\section{Introduction}

Toxoplasmosis is an important cosmopolitan zoonosis transmitted by the intracellular protozoan Toxoplasma gondii. Cats are definitive hosts and warm-blooded animals are intermediate hosts (PINTO et al., 2009).

Production animals are essential in the epidemiology of toxoplasmosis as a source of infection to humans. The animal species that are most sensitive to infection are goats, sheep, and swine, and the species that are least sensitive are cattle, horses, and birds (MILLAR et al., 2008).

In Brazil, studies conducted in Minas Gerais, Paraná, São Paulo, Bahia, and Rio Grande do Sul reported that the percentage of cattle with positive T. gondii antibodies varied from $1.03 \%$ to $49.17 \%$ (COSTA; COSTA, 1978; COSTA, 2001; DAGUER et al., 2004; SPAGNOL et al., 2009; SANTOS, 2012). Using the IFA, Gondim et al. (1999) reported that the positivity rate in Bahia was 3.85\% and Fuji et al. (2001) observed that the positivity rate in São Paulo was $3.2 \%$. In the state of Pará, Silva et al. (2010) reported that the prevalence of infection in buffaloes was 1.1\% whereas Silva et al. (2013) found a much higher prevalence in this species $(41.6 \%)$.

The presence of definitive hosts for $T$. gondii, including domestic cats, in cattleproperties, is a risk factor for the seroprevalence of infection (ALBUQUERQUE et al., 2011; SANTOS, 2012). The extensive grazing system used in Brazil also favors infection with $T$. gondii (MARANA et al., 1995; MILLAR et al., 2008).

The state of Pará has the fourth largest cattle herd and the largest buffalo herd in Brazil, with approximately 21 million and 500,000 animals, respectively (PARÁ, 2014). Moreover, Pará is the largest exporter of live animals, and many 
slaughterhouses in this state are suitable for exporting beef. Therefore, knowing the distribution of infection with $T$. gondiiin production animals is essential because of the economic, social, and public health importance of this activity to the state.

In addition, few studies to date evaluated the risk factors associated with T. gondii infection in bovine herds in the state of Pará. Therefore, the objective of this study is to evaluate the risk factors associated with the epidemiology of toxoplasmosis and the prevalence of anti-T. gondii antibodies in cattle and buffaloes reared in all mesoregions of the state of Pará, Brazil.

\section{Materials and Methods}

The municipalities were selected by the rate of animal movement. For this purpose, Animal Movement Guidelines (AMGs) issued in 2010 and 2011 by the Epidemiological Surveillance Service (ESS) of the Agriculture and Livestock Defense Agency of the state of Pará (Agência de Defesa Agropecuária do Estado do Pará-ADEPARÁ) were used. The data from the AMGs were grouped by municipality, microregion, and mesoregion, aspreviously established by IBGE. Network analysis (flow) was conducted using the Terra View software version 4.2 (PluginFlow). Furthermore, algorithms developed at the Laboratory of Epidemiology and Biostatistics of the School of Veterinary Medicine and Animal Science of the University of São Paulo (Laboratório de Epidemiologia e Bioestatística da Faculdade de Medicina Veterinária e Zootecnia da USP-LEB/FMVZ/USP) were used, allowing the selection of rural properties located in the municipalities with the highest inflow of cattle and buffaloes.

The FreeCalc software version 2, recommended by the OIE, was used to calculate the sample size using hypergeometric distribution and the formula proposed by Noordhuizenet al. (1998), [1-(1C) $1 /(\mathrm{D} *$ SENS $)] *[\mathrm{M}-(\mathrm{D} *$ SENS-1)/2], where $\mathrm{C}$ is the level of confidence, $\mathrm{M}$ is the number of units (animals/herds) at risk, D is the number of units with disease/infection, and SENS is the test sensitivity. The minimum sample size was 312 animals.

For the seroepidemiological survey, blood samples were collected in 2011 and 2012 from 2,070 bovines (1,749 cattle and 321 buffaloes) in 100 rural properties from 51 municipalities from all mesoregions of the state. The evaluated variables were animal species, gender, age, presence/number of domestic cats, and type of farm.

A random sampling method was used to select the animals in each chosen property. Blood samples were obtained by aseptic puncture of the jugular vein. The sera fractions were separated, labeled, and stored at -12 to $-18^{\circ} \mathrm{C}$ until serological analysis.

Indirect immunoenzymatic assay (iELISA), described by Cavalcante (2004), and the indirect immunofluorescence assay (IFA), described by Chiari et al. (1987) with some modifications, were performed in duplicate using commercially available Imunodot ${ }^{\circledR}$ kits for detecting $T$. gondii-specific IgG antibodies. In the IFA assay, the control samples at the dilution of 1:64 were considered positive.

In both techniques, the positive controls were sera of buffaloes and cattle with high antibody titers in IELISA and IFA, and the negative controls were sera of newborn buffaloes and cattle. The test sera and positive and negative controls were diluted 1:200. The absorbance was read at $405 \mathrm{~nm}$ using an iELISA reader.

The cut-off index (CI) - the mean optical density (OD) of negative-control sera multiplied by factor 2.5-was calculated. The samples with $\mathrm{OD} \geq$ CI were considered positive for $T$. gondii whereas samples with $\mathrm{OD}<\mathrm{CI}$ were considered negative for T. gondii.

The results were analyzed using the chi-square test with a level of significance of $5 \%$ and the odds ratio (OR) with a 95\% confidence interval. All results were statistically treated using BioEstat software version 5.0 (AYRES et al., 2007). 


\section{Results}

In iELISA and IFA, the mean prevalence of antibodies to $T$. gondii in the evaluated animals was $35.79 \%$ and $45.12 \%$, respectively, corresponding to $34.48 \%$ and $44.14 \%$ in cattle and $42.99 \%$ and
$50.47 \%$ in buffaloes, respectively.

The mesoregion of Marajó had the highest prevalence of antibodies to $T$. gondii, corresponding to $42.86 \%$ and $50.50 \%$ in iELISA and IFA, respectively (Table 1).

Table 1. Distribution of Toxoplasma gondii-positive samples using ELISA and IFA by mesoregion in the state of Pará, 2015.

\begin{tabular}{cccc}
\hline Mesoregion of Pará & Animals N* $(\%)$ & \multicolumn{2}{c}{ Animals with positive IgG } \\
\cline { 3 - 4 } & & ELISA n** (\%) & IFA n** (\%) \\
\hline Southeast & $1177(56.85 \%)$ & $430(36.53 \%)$ & $538(45.71 \%)$ \\
Northeast & $392(18.97 \%)$ & $119(30.35 \%)$ & $161(41.07 \%)$ \\
Marajó & $301(14.53 \%)$ & $129(42.86 \%)$ & $152(50.50 \%)$ \\
Lower Amazon & $132(6.37 \%)$ & $42(31.81 \%)$ & $54(40.91 \%)$ \\
Southwest & $45(2.17 \%)$ & $17(37.78 \%)$ & $21(46.67 \%)$ \\
Metropolitan area of Belém & $23(1.11 \%)$ & $4(17.39 \%)$ & $8(34.78 \%)$ \\
\hline TOTAL & $\mathbf{2 0 7 0 ( 1 0 0 \% )}$ & $\mathbf{7 4 1 ( 3 5 . 7 9 \% )}$ & $\mathbf{9 3 4 ( 4 5 . 1 2 \% )}$ \\
\hline
\end{tabular}

$* \mathrm{~N}=$ total animals; $* * \mathrm{n}=$ number of positive animals.

In the iELISA, the prevalence of antibodies to $T$. gondii in buffaloes aged 6 to 12 months was $48.33 \%$ $(58 / 120)$ in males and $26.03 \%(19 / 73)$ in females $(\mathrm{p}<0.05)$. In buffaloes aged 13 to 24 months, the prevalence of antibodies was $61.43 \%(43 / 70)$ in males and $31.03 \%(18 / 58)$ in females $(\mathrm{p}<0.05)$.
In the IFA, the prevalence of antibodies to T. gondiiin buffaloes aged 6 to 12 months was $51.66 \%(62 / 120)$ in males and $42.46 \%(31 / 73)$ in females ( $p>0.05$ ). In the age range 13 to 24 months, the prevalence was $65.71 \%(46 / 70)$ in males and $39.65 \%(23 / 58)$ in females $(\mathrm{p}<0.05)$ (Table 2$)$.

Table 2. Frequency of antibodies to T. gondii using ELISA and IFA by age group and genderof buffaloes raised in the state of Pará, Brazil.

\begin{tabular}{|c|c|c|c|c|c|c|}
\hline Age (months) & Test & Gender & $\mathbf{N}^{*}$ & Positive animals \% $(n * *)$ & $\mathbf{O R}^{* * * *}$ & $\mathbf{p}^{* * * *}$ \\
\hline \multirow{4}{*}{$6-12$} & \multirow{2}{*}{ ELISA } & Male & 120 & $48.33 \%(58)$ & \multirow{2}{*}{2.6587} & \multirow[b]{2}{*}{0.0035} \\
\hline & & Female & 73 & $26.03 \%(19)$ & & \\
\hline & \multirow{2}{*}{ IFA } & Male & 120 & $51.66 \%(62)$ & \multirow{2}{*}{1.4483} & \multirow{2}{*}{0.2748} \\
\hline & & Female & 73 & $42.46 \%(31)$ & & \\
\hline \multirow{4}{*}{$13-24$} & \multirow{2}{*}{ ELISA } & Male & 70 & $61.43 \%(43)$ & \multirow{2}{*}{3.5391} & \multirow{2}{*}{0.0012} \\
\hline & & Female & 58 & $31.03 \%(18)$ & & \\
\hline & \multirow{2}{*}{ IFA } & Male & 70 & $65.71 \%(46)$ & \multirow{2}{*}{2.9167} & \multirow{2}{*}{0.0057} \\
\hline & & Female & 58 & $39.65 \%(23)$ & & \\
\hline
\end{tabular}

$* \mathrm{~N}=$ total animals; $* * \mathrm{n}=$ number of positive animals; $* * * \mathrm{OR}=$ odds ratio; $* * * *$ the association was significant $(\mathrm{p}<0.05)$ using the chi-square test.

In iELISA and IFA, there was no significant the age group and animal gender (Table 3 ). difference $(p>0.05)$ in the prevalence considering 
Table 3. Frequency of antibodies to T. gondii using ELISA and IFA by age group and genderof cattle raised in the state of Pará, Brazil.

\begin{tabular}{|c|c|c|c|c|c|c|}
\hline Age (months) & Test & Gender & $\mathrm{N}^{*}$ & Positive animals \% $\left(\mathrm{n}^{* *}\right)$ & $\mathbf{O R}^{* * *}$ & $\mathbf{p}^{* * * *}$ \\
\hline \multirow{4}{*}{$6-12$} & \multirow{2}{*}{ ELISA } & Male & 470 & $38.71 \%(181)$ & \multirow{2}{*}{0.9394} & \multirow{2}{*}{0.6826} \\
\hline & & Female & 500 & $40.00 \%(200)$ & & \\
\hline & \multirow{2}{*}{ IFA } & Male & 470 & $46.38 \%(218)$ & \multirow{2}{*}{0.9076} & \multirow{2}{*}{0.4909} \\
\hline & & Female & 500 & $48.80 \%(244)$ & & \\
\hline \multirow{4}{*}{$13-24$} & \multirow{2}{*}{ ELISA } & Male & 434 & $29.72 \%(129)$ & \multirow{2}{*}{1.1461} & \multirow{2}{*}{0.4413} \\
\hline & & Female & 345 & $26.96 \%(93)$ & & \\
\hline & \multirow{2}{*}{ IFA } & Male & 434 & $40.32 \%(175)$ & \multirow{2}{*}{1.0511} & \multirow{2}{*}{0.7918} \\
\hline & & Female & 345 & $39.13 \%(135)$ & & \\
\hline
\end{tabular}

$* \mathrm{~N}=$ total animals $; * \mathrm{n}=$ number of positive animals; $* * * \mathrm{OR}=$ odds ratio $* * * *$ the association was significant $(\mathrm{p}<0.05)$ using the chi-square test.

With regard to the type of farm, the prevalence of antibodies using iELISA was $35.51 \%, 37.84 \%$, $44.64 \%$ in production, dairy, and mixed properties, respectively, without significant differences
( $\mathrm{p}>0.05$ ) whereas prevalence was $44.87 \%, 45.95 \%$, and $53.57 \%$ in these three types of properties using IFA, respectively $(\mathrm{p}>0.05)$ (Table 4$)$.

Table 4. Frequency of antibodies to T. gondii using ELISA and IFA by the type of farm and species of bovine raised in the state of Pará, Brazil.

\begin{tabular}{|c|c|c|c|c|c|}
\hline Test & Type of farm & $\mathbf{N}^{*}$ & Positive animals \% $\left(\mathrm{n}^{* *}\right)$ & $\mathrm{OR}^{* * * *}$ & $\mathbf{p}^{* * * *}$ \\
\hline \multirow{6}{*}{ ELISA } & Beef production & 1977 & $35.51 \%(702)$ & \multirow[b]{2}{*}{0.6827} & \multirow[b]{2}{*}{$0.205 \mathrm{c}$} \\
\hline & Mixed & 56 & $44.64 \%(25)$ & & \\
\hline & Dairy & 37 & $37.84 \%(14)$ & \multirow{2}{*}{0.9045} & \multirow{2}{*}{0.9045} \\
\hline & Beef production & 1977 & $35.51 \%(702)$ & & \\
\hline & Mixed & 56 & $44.64 \%(25)$ & \multirow{2}{*}{1.3249} & \multirow{2}{*}{0.6626} \\
\hline & Dairy & 37 & $37.84 \%(14)$ & & \\
\hline \multirow{6}{*}{ IFA } & Beef production & 1977 & $44.87 \%(887)$ & \multirow{2}{*}{0.7053} & \multirow{2}{*}{0.2481} \\
\hline & Mixed & 56 & $53.57 \%(30)$ & & \\
\hline & Dairy & 37 & $45.95 \%(17)$ & \multirow{2}{*}{1.0445} & \multirow{2}{*}{0.9713} \\
\hline & Beef production & 1977 & $44.87 \%(887)$ & & \\
\hline & Mixed & 56 & $53.57 \%(30)$ & \multirow{2}{*}{1.3575} & \multirow{2}{*}{0.6114} \\
\hline & Dairy & 37 & $45.95 \%(17)$ & & \\
\hline
\end{tabular}

$* \mathrm{~N}=$ total animals $; * \mathrm{n}=$ number of positive animals; $* * * \mathrm{OR}=$ odds ratio; $* * * *$ the association was significant $(\mathrm{p}<0.05)$ using the chi-square test.

With respect to the presence of cats in the properties, the seropositivity in iELISA was $20.32 \%$, $33.64 \%, 44.02 \%, 39.47 \%$, and $52.83 \%$ in properties with no cats, $1-3$ cats, $4-6$ cats, $7-9$ cats, and $>10$ cats, respectively. There was a significant difference $(p<0.05)$ in seropositivity between properties with cats and those without cats (Table 5).
For IFA, the seropositivity was $35.29 \%, 43.28 \%$, $50.54 \%, 46.49 \%$, and $58.49 \%$ in properties with no cats, $1-3$ cats, $4-6$ cats, $7-9$ cats, and $>10$ cats, respectively. There was a significant difference $(p<0.05)$ in seropositivity between the properties with cats and those without cats. This result indicates a positive correlation between the presence of cats and infection with $T$. gondii. 
Table 5. Frequency of antibodies to $T$. gondii using ELISA and IFA according to the number of cats and bovines in the state of Pará, Brazil.

\begin{tabular}{cccccc}
\hline Test & Number of cats & Number of bovines & Positive animals \% (n*) & OR $^{* *}$ & $\mathbf{p}^{* * *}$ \\
\hline & 0 & 374 & $20.32 \%(76)$ & 0.5031 & $<0.0001$ \\
& $1-3$ & 871 & $33.64 \%(293)$ & & \\
ELISA & 0 & 374 & $20.32 \%(76)$ & 0.3243 & $<0.0001$ \\
& $4-6$ & 552 & $44.02 \%(243)$ & & \\
& 0 & 374 & $20.32 \%(76)$ & 0.3911 & $<0.0001$ \\
& $7-9$ & 114 & $39.47 \%(45)$ & & \\
& 0 & 374 & $20.32 \%(76)$ & 0.2277 & $<0.0001$ \\
\hline \multirow{4}{*}{ IFA } & $>10$ & 159 & $52.83 \%(84)$ & & \multirow{2}{*}{0.0103} \\
& 0 & 374 & $35.29 \%(132)$ & 0.7147 & \\
& $1-3$ & 871 & $43.28 \%(377)$ & & \\
& 0 & 374 & $35.29 \%(132)$ & 0.5337 & $<0.0001$ \\
& $4-6$ & 552 & $50.54 \%(279)$ & & \\
& 0 & 374 & $35.29 \%(132)$ & 0.6278 & 0.0407 \\
& $7-9$ & 114 & $46.49 \%(53)$ & & \\
& 0 & 374 & $35.29 \%(132)$ & 0.3871 & $<0.0001$ \\
\hline
\end{tabular}

$* \mathrm{n}=$ number of positive animals; $* * \mathrm{OR}=$ odds ratio; $* * *$ Association was significant $\mathrm{using}$ the chi-square test $(\mathrm{p}<0.05)$.

\section{Discussion}

These results indicate that the prevalence of antibodies toT. gondii in cattle in the state of Pará using iELISA and IFA was $34.48 \%$ and $44.14 \%$, respectively. This percentage was similar to the mean value obtained in other regions of Brazil. The reported seropositivity was $48.51 \%$ (MARANA et al., 1995) and 41.4\% (DAGUER et al., 2004) in Paraná, $17.4 \%$ in Rio Grande do Sul (SANTOS, 2012), and $11.83 \%$ in Bahia (SPAGNOL et al., 2009). In Pará, Carmo et al. (2017) observed that the prevalence of anti- $T$. gondii antibodies using IFA was $40.6 \%$ in beef cattle slaughtered for consumption in the metropolitan area of Belém.

The percentage of $T$. gondiiantibodies in buffaloes was $42.99 \%$ using iELISA and $50.47 \%$ using IFA. Silva et al. (Prevalence) reported that the prevalence in Pará was $41.6 \%$ using iELISA and $36.0 \%$ using IFA. Souza et al. (2001) analyzed 411 serum samples of buffaloes for infection with $T$. gondii in São Paulo using IFA and found that 205 (49.9\%) were seropositive. However, the seropositivity rates reported by studies on buffaloes in Brazil was lower than those reported in the above studies. In this respect, the prevalence rates reported by Silva et al. (2010) in Pará, Gondim et al. (1999) in Bahia, and Fuji et al. (2001) in São Paulo were 1.1\%, 3.85\%, and $3.2 \%$ using IFA, respectively. Santos (2012) used IFA and foundthat the seropositivity was $27.2 \%$ in Rio Grande do Sul. Brasil et al. (2015) evaluated 136 buffaloes from 14 properties in Paraíba and found that the seropositivity was $12.5 \%$. Guerra et al. (2014) hypothesized that variations in seroprevalence worldwide could be attributed to differences in ecosystems and the results of the serological tests used.

In the joint analysis of the variables, including species, sex, and age, there were no significant differences $(p>0.05)$ in the prevalence of antibodiesin cattle. This result corroborates the study by Carmo et al. (2017) in Pará and Daguer et al. (2004) in Paraná, wherein there was no significant difference in prevalence between males and females ( $p>0.05$ ). However, El Fahal et al. (2013) reported that the prevalence of antibodies in cattle in Sudan was higher in males $(30.8 \%)$ than in females $(11.9 \%)$ 
using ELISA whereas Daguer et al. (2004) found no significant differences in prevalence according to the age of the studied animals in Paraná.

Male buffaloes were significantly more affected, and the age group 13 to 24 months presented the highest seropositivity rate. In the state of São Paulo, female buffaloes aged 60 to 72 months carrying antibodies to $T$. gondiirepresented $62.5 \%$ of the positive animals, and $39.2 \%$ of the females aged 2 to 4 years contained antibodies toT. gondii (SOUZA et al., 2001). García and Vasquéz (1990) and Acha and Szyfres (1992) reported that the prevalence of toxoplasmosis was increased with age because there was a higher risk of exposure to the parasite as the age of the animals was increased.

With respect to the type of farm, the seroprevalence in production farms was higher than that in dairy and mixed farms (Table 3). This result may be because most of the beef cattle are reared under an extensive grazing system, which favors infection with T. gondii (MARANA et al., 1995; MILLAR et al., 2008).

There was a positive correlation $(p<0.05)$ between the number of cats and the prevalence of T. gondii antibodies in cattle farms in Pará. The higher was the number of cats in the properties, the higher was the seroprevalence. Santos (2012) observed that the presence of cats in the properties might indicate an environment contaminated with T. gondii. The results of this study corroborate with those of Albuquerque et al. (2011), whereinthe number of cats and human contact with the animals were associated with the seroprevalence of $T$. gondii in cattle. However, the results differ from those of Santos (2008), who did not find a positive correlation between the prevalence of $T$. gondii and the number of cats.

Anderlini et al. (2001), Albuquerque et al. (2011), and Guerra et al. (2014) using cattle, and Brasil et al. (2015) using buffaloes, consider that the semi-intensive farming system is a risk factor for toxoplasmosis, and justified that under these conditions, there was a higher probability of contact with oocysts because the animals remained part of the day in pastures and part of the day in confinement and consequently were exposed to both environments. Anderlini et al. (2001) observed that animals kept under an intensive farming system were at higher risk of contact with oocysts present in cat feces, which increased the risk of infection with $T$. gondii.

Although the transmission of toxoplasmosis via consumption of raw or undercooked beef is still unclear, Millar et al. (2008), Guerra et al. (2014), and Carmo et al. (2017) reported that the meat of these animals might contain viable cysts and be a source of infection for humans and domestic and carnivorous animals if consumed. This condition was confirmed by Lora et al. (2007) using PCR to detect genomic material of $T$. gondii in bovine meat, and $48.33 \%$ of the analyzed samples were positive for the parasite. The authors concluded that there was a potential risk for infection via consumption of raw or undercooked meat.

The prevalence of antibodies was higher in the mesoregion of Marajó. It should be emphasized that animal sanitation in Marajó Island is usually poor because of the lack of adequate animal management, and the physical characteristics of the region limit livestock productivity (BARBOSA, 2005). Ahmad and Qayyum (2014) observed that the number of animals positive for antibodies to $T$. gondii was significantly higher in farms with poor hygiene, and the presence of cats in the vicinity of the farm contributed to the spread of infection.

\section{Conclusions}

Our results indicated that infection with $T$. gondiiwas high in cattle raised in the state of Pará. The high prevalence of seropositive cattle and buffaloes suggests that these animals may be a source of infection to humans. 
The high percentage of infection was correlated with the presence of cats in the studied properties, evidencing that cats are crucial in the epidemiology of toxoplasmosis.

\section{Acknowledgments}

We are grateful to the Agricultural Defense Agency of Pará for providing the data, to cattle farmers of the state of Pará, and to the Graduate Course in Animal Science.

\section{References}

ACHA, P.; SZYFRES, B. Zoonosis y EnfermedadesTransmisiblescomunes al hombre $y$ losanimales. 3. ed. Washington USA: OPS, 1992. 798 p.

AHMAD, N.; QAYYUM, M. Seroprevalence and risk factors for toxoplasmosis in large ruminants in northern Punjab, Pakistan. Journal of Infection in Developing Countries, Punjab, v. 8, n. 8, p. 1022-1028, 2014.

ALBUQUERQUE, G. R.; MUNHOZ,A. D.; FLAUSINO, M. T. W.; MEDEIROS, S. M.; LOPES, C. W. G. Risk factors associated with Toxoplasma gondiiinfection in dairy cattle, State of Rio de Janeiro. Pesquisa Veterinária Brasileira, Rio de Janeiro, v. 31, n. 4, p. 287-290, 2011.

ANDERLINI, G. A.; MOTA, R. A.; FARIA, E. B.; CAVALCANTI, E. F.; VALENCA, R. M. B.; PINHEIRO JUNIOR, J. W.; ALBUQUERQUE, P. P. F.; SOUZA NETO, O. L. Occurrence and risk factors associated with infection by Toxoplasma gondiiin goats in the state of Alagoas, Brazil. Revista da Sociedade Brasileira Medicina Tropical, Alagoas, v. 44, n. 2, p. 157-162, 2001.

AYRES, M.; AYRES J. R. M.; AYRES, D. L.; SANTOS, A. S. BioEstat 5.0 - aplicações estatísticas nas áreas das ciências biológicas e médica. Belém: Sociedade Civil Mamirauá; Brasília: CNPq, 2007. 290 p.

BARBOSA, N. G. S. Bubalinocultura no Estado do Pará. Revista Brasileirade Reprodução Animal, Belo Horizonte, v. 29, n. 1, p. 34-38, 2005.

BRASIL, A. W. L.; PARENTONI, R. N.; FEITOSA, T. S. F.; BEZERRA, C. S.; VILELA, V. L. R.; PENA, H. F. J.; AZEVEDO, S. S. Risk factors for Toxoplasma gondiiand Neosporacaninumseropositivity in buffaloes in Paraiba State, Brazil. Brazilian Journal of Veterinary Parasitology, Paraiba, v. 24, n. 4, p. 459-463, 2015.
CARMO, E. L.; MORAIS, R. A. P. B.; LIMA, M. S.; MORAES, C. C. G.; ALBUQUERQUE, G. R.; SILVA, A. V.; PÓVOA, M. M. Anti-Toxoplasma gondiiantibodies in beef cattle slaughtered in the metropolitan region of Belém, Brazilian Amazon. Brazilian Journal of Veterinary Parasitology, Belém, v. 26, n. 2, p. 226-230, 2017.

CAVAlCANTE, A. C. R. Toxoplasmose Caprina no Ceará:soroepidemiologia e caracterização de cepas de Toxoplasma gondii. 2004. Tese (Doutorado em Parasitologia) - Instituto de Ciências Biológicas, Belo Horizonte.

CHIARI, C. A.; LIMA, J. D.; LIMA, W. S.; ANTUNES, C. M. F. Soro-epidemiologia da toxoplasmose caprina em Minas Gerais, Brasil. 1987. Tese (Doutorado em Ciências) - Instituto de Ciências Biológicas, Belo Horizonte.

COSTA, A. J.; COSTA, E. P. Frequência de bovinos reagentes à imunofluorescência indireta para Toxoplasma gondii em Poços de Caldas, MG, Brasil. Arquivos da Escola de Veterinária da UFMG, Minas Gerais, v. 30, n. 1, p. 47-51, 1978.

COSTA, G. H.; CABRAL, D. D.; VARANDAS, N. P.; SOBRAL, E. A.; BORGES, F. A.; CASTAGNOLLI, K. C. Frequência de anticorpos anti-Neosporacaninume anti-Toxoplasmagondiiem soros de bovinos pertencentes aos estados de São Paulo e de Minas Gerais. Revista Semina: Ciências Agrárias, Londrina, v. 22, n. 1, p. 6168, 2001.

DAGUER, H.; VICENTE, R. T.; COSTA, T.; HAMANN, M. P. V.; AMENDOEIRA, M. R. R. Soroprevalência de anticorpos anti-Toxoplasmagondiiem bovinos e funcionários de matadouros da microrregião de Pato Branco, Paraná, Brasil. Ciência Rural, Santa Maria, v. 34, n. 4, p. 1133-1137, 2004.

EL FAHAL, A. M.; ELHASSAN, A. M.; HUSSIEN, M. O.; ENAN, K. A.; MUSA, A. B.; HUSSEIN, A. M. Seroprevalence of Toxoplasma gondiiin dairy cattle with reproductive problems in Sudan. Journal of Veterinary Science, Sudan, v. 63, n. 1, p. 312-315, 2013.

FUJI, T. U.; KASAI, N.; VASCONCELLOS, S. A.; RICHTZENHAIN, L. J.; CORTEZ, A.; SOUZA, S. L. P.; BARUSELLI, P. S.; NISHI, S. M.; FERREIRA, F.; GENNARI, S. M. Anticorpos anti-Neosporacaninume contra outros agentes de abortamentos em búfalas da Região do Vale do Ribeira, São Paulo, Brasil. Arquivos Instituto Biológico, São Paulo, v. 68, n. 2, p. 5-9, 2001.

GARCÍA, V. Z.; ROSARIO, C. R; SOLARGOSALGRADO, M. Prevalence of antibo diesagonist 
Toxoplasma gondii in sheepandgoats in threestates of México. Preventive Veterinary Medicine, v. 10, 1-2, p. 25-29, 1990.

GONDIM, L. F.; BARBOSA, H. V.; RIBEIRO C. H. A.; SAEKI H. Serological survey of antibodies to Toxoplasma gondiiin goats, sheep, cattle and water buffaloes in Bahia State, Brasil. Journal Veterinary Parasitology, Bahia, v. 82, n. 1, p. 273-276, 1999.

GUERRA, N. R.; ALVES, B. H. L. S.; FARIAS, M. P. O.; MOTA, R. A.; ALVES, L. C. Frequency of Toxoplasma gondiiantibodies in bovines in the state of Pernambuco, Brazil. Revista Brasileira de Parasitologia Veterinária, Pernambuco, v. 23, n. 3, p. 417-419, 2014.

LORA, F.; ARICAPA, H. J.; PÉREZ, J. E.; ARIAS, L. E.; IDARRAGA, S. E.; MIER, D.; GÓMEZ, J. E. Detección de Toxoplasma gondiien carnes de consumo humano por la técnica de reacción em cadena de lapolimerasa em três ciudades del ej ecafetero. Infectio, Eje Cafetero, v. 11, n. 3, p. 117-123, 2007.

MARANA, E. R. M.; VENTURINI, A. C. H.; FREIRE, R. L.; VIDOTTO, O.; NAVARRO, I. T. Ocorrência de anticorpos anti-Toxoplasmagondii em bovinos de leite, do norte do Paraná- Brasil. Revista Semina: Ciências Agrárias, Londrina, v. 16, n. 1, p. 40-42, 1995.

MILLAR, P. R.; SOBREIRO, L. G.; BONNA, I. C. F.; AMENDOEIRA, M. R. R. A importância dos animais de produção na infecção por Toxoplasma gondii no Brasil. Revista Semina: Ciências Agrárias, Londrina, v. 29, n. 3, p. 693-706, 2008.

NOORDHUIZEN, J. P. T. M.; FRANKENA, K.; HOOFD, C. M.; GREAT, E. A. M. Application of quantitative methods in veterinary epidemiology. The Canadian Veterinary Journal, Netherlands, v. 39, n. 6, p. 362.1998.

PARÁ. AGÊNCIA DE DEFESA AGROPECUÁRIA DO ESTADO DO PARÁ - ADEPARÁ. Relatório de campanha de vacinação de febre aftosa de novembro de 2014. Belém: Governo do Estado do Pará, 2014. p. 6.
PINTO, L. D.; ARAUJO, F. A. P.; STOBB, N. S.; MARQUES, S. M. T. Soroepidemiologia de Toxoplasma gondiiem gatos domiciliados atendidos em clínicas particulares de Porto Alegre, RS, Brasil. Ciência Rural, Santa Maria, v. 39, n. 8, p. 2464-2469, 2009.

SANTOS, L. M. J. F. Soroprevalencia de Toxoplasma gondii em bubalinos e bovinos que compartilham a mesma área no sul do Rio Grande do Sul. 2012. Dissertação (Mestrado em Parasitologia) - Universidade Federal de Pelotas, Pelotas.

SANTOS, T. R. Prevalência de anticorpos antiToxoplasmagondiiem bovinos, cães e humanos da região sudoeste do estado de Mato Grosso. 2008. Dissertação (Mestrado em Medicina Veterinária) - Faculdade de Ciências Agrárias e Veterinárias. Universidade Estadual Paulista, Jaboticabal.

SILVA, J. B.; FONSECA, A. H.; ANDRADE, S. J. T.; SILVA, A. G. M.; OLIVEIRA, C. M. C.; BARBOSA, J. D. Prevalência de anticorpos anti-Toxoplasmagondiiem búfalos (Bubalusbubalis) no Estado no Pará. Pesquisa Veterinária Brasileira, Marajó, v. 33, n. 5, p. 581 - 585, 2013.

SILVA, S. P.; MOTA, R. A.; FARIA, E. B.; FERNANDES, E. F. T. S.; ORESTES, L. S. N.; ALBUQUERQUE, P. P. F.; DIAS, H. L. T. Anticorpos IgGanti-Neosporacaninume Toxoplasma gondiiem búfalas (Bubalusbubalis) criadas no estado do Pará. Pesquisa Veterinária Brasileira, Pará, v. 30, n. 5, p. 443-446, 2010.

SOUZA, L. M.; NASCIMENTO, A. A.; FURUTA, P. I.; BASSO, L. M. S.; SILVEIRA, D. M.; COSTA, A. J. Detecção de anticorpos contra Neosporacaninume Toxoplasma gondiiem soros de bubalinos (Bubalusbubalis) no Estado de São Paulo, Brasil. Revista Semina: Ciências Agrárias, São Paulo, v. 22, n. 1, p. 3948, 2001 .

SPAGNOL, F. H.; PARANHOS, E. B.; OLIVEIRA, L. L.; MEDEIROS, S. M.; LOPES, C. W.; ALBUQUERQUE, G. R. Prevalência de anticorpos anti-Toxoplasmagondii em bovinos abatidos em matadouros do estado da Bahia, Brasil. Revista Brasileira de Parasitologia Veterinária, Jaboticabal, v. 18, n. 2, p. 42-45, 2009. 
